\title{
INFLUENCE OF SYNTHETIC FLAVORINGS ON THE MIGRATION ACTIVITY OF Tribolium confusum AND Sitophilus granarius
}

\author{
OLEKSII TITOV ${ }^{1}$, VIKTOR BRYGADYRENKO $\bigotimes^{2,3}$ \\ ${ }^{1}$ Dnipropetrovsk Medical Academy of the Ministry of Health of Ukraine, Vernadsky st., 9, Dnipro, 49044, Ukraine; e-mail: oleksii.titov007@gmail.com \\ ${ }^{2}$ Oles Honchar Dnipro National University, Gagarin av., 72, Dnipro, 49010, Ukraine; e-mail: brigad@ua.fm \\ ${ }^{3}$ Dnipro State Agrarian and Economic University, Sergiy Efremov st., 25, Dnipro, 49000, Ukraine; e-mail: \\ brigad@ua.fm
}

$\triangle$ Corresponding author

Received: 14 April 2021 / Accepted: 30 May 2021

\begin{abstract}
Titov O., Brygadyrenko V.: Influence of synthetic flavorings on the migration activity of Tribolium confusum and Sitophilus granarius. Ekológia (Bratislava), Vol. 40, No. 2, p. 163-177, 2021.

Flavorings and volatile biologically active substances, used by humans for various purposes, may potentially have fumigating, repellent, or attractive effects on various species of anthropod storage pests. Tribolium confusum Jacquelin du Val, 1863 (Tenebrionidae) and Sitophilus granarius (Linnaeus, 1758) (Curculionidae) are the two most abundant pests of grain and grain products; the damage they cause to stored products of horticulture is $5-20 \%$ of the total yield of grain crops. In the experiment, we video-recorded migratory activity of beetles and evaluated it according to standard time periods $(10,20,30,60$, and 120 seconds after the start of the experiment). No reliable influence of the 15 tested flavoring substances (benzyl alcohol, benzoic acid, toluene, hydroquinone, phenethyl alcohol, pinene, methylparaben, kojic acid, formic acid, isoamyl alcohol, tartaric acid, glycine, succinic acid, stearic acid, and ethylenediaminetetraacetic acid) on moving activity of Tribolium confusum was found. Exposure to benzyl alcohol brought a reliable decrease in locomotor activity of Sitophilus granarius (it exerted an attractant effect on imagoes as compared with the variant of the experiment without aromatic substances): 6.09 times more imagoes of $S$. granarius remained at a minimal distance from the aroma source than in the control, 6.07 more while exposed to hydroquinone, 5.50 to phenethyl alcohol, 4.50 to glycine, 3.44 to EDTA, 3.30 to toluene, 3.18 to methylparaben, 2.84 to succinic acid, 2.65 to benzoic acid, and 2.15 more when exposed to formic acid compared with the control variant of the experiment. Other surveyed flavoring substances (benzyl alcohol, pinene, kojic acid, isoamyl alcohol, tartaric acid, and stearic acid) had no significant effect on migratory activity of imagoes of $S$. granarius. The results allow us to recommend benzyl alcohol, hydroquinone, phenethyl alcohol, and glycine as potential luring substances or components of multicomponent flavoring mixtures during the assessment of the number of $S$. granarius in grain storage and processing facilities.
\end{abstract}

Key words: pest control, wheat weevil, confused flour beetle, repellent, attractant, grain storage, flour storage, bakery products.

\section{Introduction}

Volatile organic compounds synthesized by plants-their essential oils-are multicomponent mixtures that are oriented toward antimicrobial activity and allelopathic effect on competing species of plants but most importantly toward phytophage insects and vertebrates. "Dialogue" between the plants and insects has been taking place for several hundreds of millions of years, and therefore we may analyze only the recent "answers" in this "dialogue." We are unable to understand the storyline of this evolutional conversation between plants and many species of their phytophages and assess the changes or adaptations the phytophages obtained while accustoming to the chemical influence of plants. It is unclear to researchers why a plant needs to synthesize essential oil that contains up to half hundred separate constituents. Even less clear is the strange reaction of phytophages to separate components of essential oil: for example, the luring effect of a low concentration of the substance and frightening effect of a high one, synergic effects of various aromatic substances or, on the contrary, weakening of the insect-attractant effect of a mixture of two attractants in essential oil (Dissanayaka et al., 2020a). These are only the most recent adaptations to have emerged naturally in the process of mutual evolution of plant and phytophage through millions of generations of their continuous struggle.

In the process of organic synthesis and the use of numerous chemical substances, humans are interfering in the "dialogue" between plant and phytophage. It is hard to provide an ecological assessment of this interference: the strongest interactions that may result in a phytophage's death or more or less noticeable behavioral reaction (oriented migration of an insect in the concentration gradient of a volatile organic compound) are studied better. Unfortunately, only some flavoring substances used in the household have been tested against insects that live in house-

(c) The Author(s) 2021. This is an open access article distributed under the terms of the CC BY-NC-ND license.

https://content.sciendo.com/view/journals/eko/eko-overview.xml 
holds (Wright, 1966; Daglish et al., 2018; Yasir et al., 2020). The present study had the goal of filling this gap. We wanted not only to determine the fumigant, repellent, or luring activities of individual organic substances or develop a new method of killing storage pests but also show that the effect on populations of insects is experienced through a much more subtle way than death and migration from or to the aroma source. Some studies assume that sex pheromones aggregation is derived from aggregation pheromones (Levinson, Levinson, 1995).

The main species of insect storage pests annually destroy products amounting to over 1 billion dollars (Boyer et al., 2011). More recent publications provide even higher numbers. For example, post-harvest grain losses of maize in Africa are estimated at US $\$ 4$ billion annually, including $10-88 \%$ of maize loss due to storage pests (Stuhl, 2019). Therefore, their study is of important practical significance. There are over 400 species of storage pests that damage grain and grain products during storage. Their species composition varies in different countries. For example, in Ukraine, there are 116 species, including 51 species of coleopterans (Serednyak, Fedorenko, 2014).

The confused flour beetle, Tribolium confusum Jacquelin du Val, 1863 (Coleoptera, Tenebrionidae), is one of the most common storage insect pests, which causes damage equaling 5-30\% of global agricultural production, and one of the most harmful pests of flour mills around the globe. The red flour beetle, T. castaneum (Herbst, 1797), causes great harm in flour mills and storages (Duehl et al., 2011; Doud, Phillips, 2020). T. confusum and T. castaneum are some of the first beetles to have a completely sequenced genome and, therefore, may be potentially used as model organisms in various studies (Adamski et al., 2019).

The second important group of storage pests is composed of species of Sitophilus genus (Coleoptera, Curculionidae): the flightless wheat weevil S. granarius (Linnaeus, 1758) and also some flying species of this genus-rice weevil, S. orizae (Linnaeus, 1763), maize weevil, S. zeamais (Motschulsky, 1855), and also other relative species of this genus.

Together, species of Tribolium and Sitophilus genera have been the most significant storage pests throughout the historical development of human civilization. Several polyphagous coleopterans and lepidopterans, currently considered storage pests, are presumed to have evolved from free-living ancestral species, becoming able to grow and reproduce on stored, desiccated, and often nutrient-poor products (Levinson, Levinson, 1995). These species are distributed worldwide, and no doubt, if human will ever inhabit other planets and asteroids, developing artificial fragments of the terrestrial biosphere in the cosmos, these species will follow people and be among the first undesirable guests on space ships and in settlements of people on the Moon, Mars, asteroids, etc. Therefore, the study of subtle mechanisms of regulation of behaviors of species of Tribolium and Sitophilus genera is an important scientific and practical task.

Aggregation pheromones are usually introduced to the substrate by long-lived and feeding males of several coleopteran species at places where they form bisexual assemblies to feed, mate, and reproduce (Levinson, Levinson, 1995). Despite the relevance of the development of methods of using essential oils or their constituents as insecticidal preparations, their introduction into technologies of integrated control of pests remains impossible due to the insufficient amount of data on this problem, difficulties in standardization, and control of the quality of plant produc- tion. Various authors indicate that reaction of insects to odorants changes over time. Collins et al. (2008) point out that various types of dispensers have different effectiveness against $S$. granarius and other species of storage pests; the greater part of the attractant evaporates in the first days after its application, and after several days, the attractiveness of the trap decreases. The optimal time was determined to be equal to $1 \mathrm{~h}$, or at least it was as effective as longer periods (Morgan et al., 1998). Thus, in our studies, we decided to reduce the time of the experiment as far as we possibly could, assessing particularly the initial reaction of beetles to the influence of the odorant during the first two minutes of the experiment.

The objective of this article was to assess the first reaction of imagoes of Tribolium confusum and Sitophilus granarius 10, 20, 30,60 , and 120 seconds after the beginning of exposure to the aroma of synthetic flavoring substances in the conditions of a laboratory experiment.

\section{Material and methods}

A total of 15 chemically pure flavoring compounds were used in the experiment (Table 1) conducted in October-November 2019. Before the start of the experiments, the beetles were kept in a 20-liter container with oat wheat (for Tribolium confusum) or wheat grain (for Sitophilus granarius). The beetles for the experiment were selected randomly by sieving the substrate through a sieve with cells of the corresponding diameter, trying to disturb the beetles as little as possible.

On a blank sheet of paper (for each experiment we used a new sheet of paper), we drew six concentric circles of $4,6,8,12,16$, and $20 \mathrm{~cm}$ (Fig. 1) and put the sheets in a plastic box. In the center of a circle with the least diameter $(4 \mathrm{~cm})$, we put perforated capsules with cotton balls of the diameter of $0.4 \mathrm{~cm}$, moistened by one droplet $(0.06 \mathrm{~mL})$ of a certain chemical substance. We carefully put 190-210 imagoes of Tribolium confusum or Sitophilus granarius (Fig. 1) on top and recorded their movements on a video camera for $120 \mathrm{sec}$. Using the footage, we counted the beetles after 10, 20,30,60, and 120 sec inside each circle. Each experiment was replicated 10-fold.

The rate of moving of beetles of Tribolium confusum and Sitophilus granarius was highly affected by temperature and light in the place of their multiday cultivation before the experiment and in the place of performing the experiment (dull, diffuse artificial light, absence of gradients of temperature and moisture, absence of noise influence, and vibration of objects). It was very important to remove possible air movements above the place where the experiment was carried out, and therefore the experiment was conducted as carefully as possible in the plastic container. All the manipulations with beetles were done carefully to avoid mechanical damage to the imagoes. Beetles taken for this experiment were not used for the experiments for the second time in order not to distort the results.

In total, using 960 photos, we determined the positions of 320 thou insects: 200 insects in one replication of the experiment $\times 5$ time periods according to which we counted $(10,20,30,60$, and $120 \mathrm{sec}) \times 10$ replications in the experiment with a particular substance $\times 16$ (15 substances and the control group $) \times 2$ species of insects (Tribolium confusum and Sitophilus granarius).

The experiments were carried out in the laboratory with even light and temperature, with standard electric light, avoiding exposure of the beetles to direct sunlight. The length of daylight was coherent with the stages we described earlier (Martynov et al., 2019). 
Table 1. Brief characteristics of use and biological effects of using the tested chemical substances.

\begin{tabular}{|c|c|c|c|}
\hline Name & Use & Biological effects & $\begin{array}{c}\text { Codex } \\
\text { Alimentarius }\end{array}$ \\
\hline Benzyl alcohol & $\begin{array}{l}\text { Solution of ink, paints, varnish, and epoxy, and in the } \\
\text { production of soup and artificial taste substances }\end{array}$ & $\begin{array}{l}\text { Moderate toxicity; high concentrations can } \\
\text { damage the mucous membranes and lead to } \\
\text { vasodilation, hypotonia, seizures, and paralysis }\end{array}$ & $\mathrm{E}_{1519}$ \\
\hline Benzoic acid & $\begin{array}{l}\text { In chemical and food production as an inhibitor of } \\
\text { corrosion }\end{array}$ & $\begin{array}{l}\text { The substance of average toxicity; may } \\
\text { irritate the mucous membranes of humans }\end{array}$ & $\mathrm{E}_{210}$ \\
\hline Toluene & $\begin{array}{l}\text { To obtain explosives (trinitrotoluene), colorings, and } \\
\text { other compounds such as solvent }\end{array}$ & $\begin{array}{l}\text { Weak narcotic effect; pairs of toluol can } \\
\text { affect the nervous system after penetrating } \\
\text { the skin and respiratory organs }\end{array}$ & - \\
\hline Hydroquinone & $\begin{array}{l}\text { In analytical chemistry, it is used to identify pH of } \\
\text { some ions of metals; in industry, it is used in the } \\
\text { production of organic colorings, medicinal preparations, } \\
\text { photographic materials, food products, and natural } \\
\text { rubber (caucho) and as an antioxidant; in medicine and } \\
\text { perfume industry, it is used as an inhibitor of reaction of } \\
\text { polymerization of vinyl polymers }\end{array}$ & $\begin{array}{l}\text { Low-level disinfectant and toxic in large } \\
\text { amounts }\end{array}$ & - \\
\hline $\begin{array}{l}\text { Phenylethyl } \\
\text { alcohol }\end{array}$ & $\begin{array}{l}\text { In the perfume industry, it is used as a substitute for } \\
\text { natural rose oil }\end{array}$ & $\begin{array}{l}\text { Toxic substance; can irritate the skin, } \\
\text { mucous membranes of eyes, and respiratory } \\
\text { tracts }\end{array}$ & - \\
\hline Pinene & $\begin{array}{l}\text { For the synthesis of camphor and other chemical } \\
\text { compounds, as a solvent for varnish and paints, raw } \\
\text { material for obtaining pine rosin, polyterpene resins, } \\
\text { terpineol, and other aromatic substances }\end{array}$ & $\begin{array}{l}\text { An important component of resin of } \\
\text { coniferous trees }\end{array}$ & - \\
\hline Methylparaben & $\begin{array}{l}\text { Broadly used as a preservative, including medicinal and } \\
\text { cosmetic preparations }\end{array}$ & $\begin{array}{l}\text { Can cause an allergic reaction (mostly on } \\
\text { the skin) }\end{array}$ & $\mathrm{E}_{218}$ \\
\hline Kojic acid & $\begin{array}{l}\text { In the food industry, it is used in the production of } \\
\text { cosmetics, to preserve the color of substance, etc. }\end{array}$ & $\begin{array}{l}\text { Soft inhibitor of development of pigment in } \\
\text { the tissues of plants and animals }\end{array}$ & - \\
\hline Formic acid & $\begin{array}{l}\text { As a preservative and antibacterial agent in the } \\
\text { preparation of fodder, slows decomposition, used with } \\
\text { after-chromed dye, against parasites in beekeeping, as a } \\
\text { solvent in some chemical reactions, medicine }\end{array}$ & $\begin{array}{l}\text { Toxicity depends on concentration: up to } \\
10 \% \text { causes irritation, over } 10 \% \text { corrosive. } \\
\text { Concentrated evaporation affects the } \\
\text { mucous membranes }\end{array}$ & $\mathrm{E}_{236}$ \\
\hline Isoamyl alcohol & $\begin{array}{l}\text { As a solvent in the industry to obtain isoamyl acetate, } \\
\text { preparation of essence of nitrocellulose varnishes and } \\
\text { amyl nitrite, in perfume industry; medicine }\end{array}$ & $\begin{array}{l}\text { Toxic substance; affects the central nervous } \\
\text { system and has a narcotic effect }\end{array}$ & - \\
\hline Tartaric acid & $\begin{array}{l}\text { In the food industry, medicine; to obtain its ethers and } \\
\text { salts (tartrate), in analytical chemistry in the content } \\
\text { of reagent Fehling's solution to detect aldehydes, in the } \\
\text { process of dying fabric, etc. }\end{array}$ & $\begin{array}{l}\text { Toxic substance; can cause irritation of the } \\
\text { skin, mucous membranes, and respiratory } \\
\text { tracts }\end{array}$ & $\mathrm{E}_{334}$ \\
\hline Glycine & In medicine, food industry, etc. & $\begin{array}{l}\text { Constituent of many proteins and } \\
\text { biologically active compounds }\end{array}$ & $\mathrm{E}_{640}$ \\
\hline Succinic acid & $\begin{array}{l}\text { In analytical chemistry; it is used in chemical synthesis } \\
\text { for obtaining polymer materials and resins and in the } \\
\text { food industry }\end{array}$ & $\begin{array}{l}\text { Takes part in the process of cellular } \\
\text { respiration of living organisms }\end{array}$ & $\mathrm{E}_{363}$ \\
\hline Stearic acid & $\begin{array}{l}\text { In cosmetics, production of candles and rubber. Sodium, } \\
\text { calcium, and lead stearates as components of greases }\end{array}$ & $\begin{array}{l}\text { One the most common fatty acids in nature, } \\
\text { as triacylglycerol it is a constituent of lipids }\end{array}$ & - \\
\hline EDTA-Na2 & $\begin{array}{l}\text { In analytical chemistry; cellulose-paper industry, } \\
\text { production of preparation of household chemistry, food } \\
\text { preservation; photography, etc. }\end{array}$ & $\begin{array}{l}\text { Can irritate the skin, mucous membranes } \\
\text { of eyes and respiratory tracts and cause } \\
\text { symptoms of bronchitis }\end{array}$ & $\mathrm{E}_{386}$ \\
\hline
\end{tabular}

Note: Information on the effect of aromatic substances is obtained from the publications by Lieber (1988), Burnett et al. (2010), Raab et al. (2010), Rivas da Silva et al. (2012), Johnson Jr et al. (2016), Johnson et al. (2017), and others.

Daily fluctuations of temperature did not exceed $2{ }^{\circ} \mathrm{C}(+21 \ldots+23$ ${ }^{\circ} \mathrm{C}$ ), and relative air moisture was $60-70 \%$.

The obtained results were analyzed in Statistica 8.0 (StatSoft Inc., USA) software. The differences between the selec- tions were determined using single-factor disperse analysis (ANOVA) and considered reliable at $P<0.05$. The normality of the data distribution was examined using the Shapiro-Wilk $W$-test. 


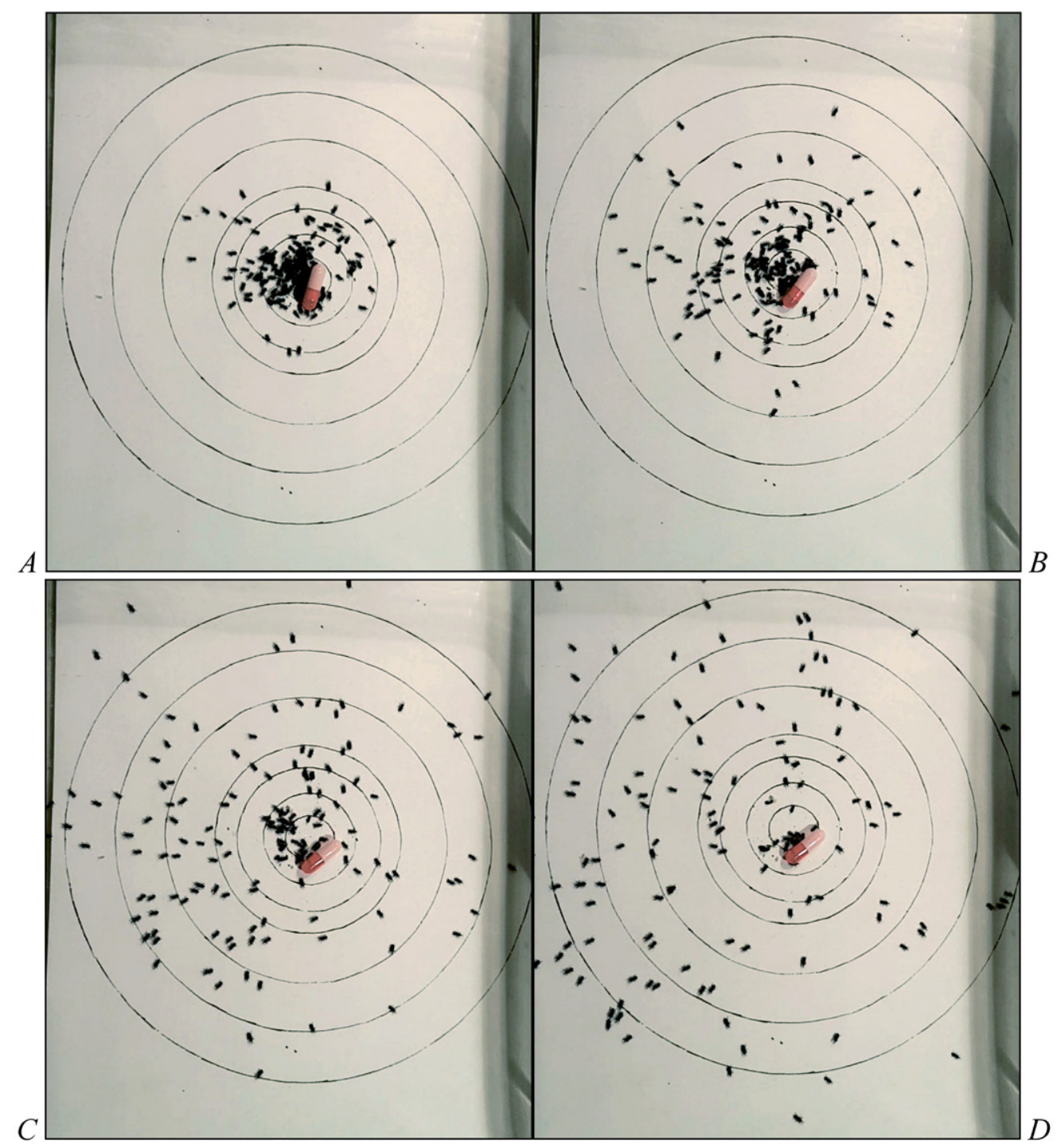

Fig. 1. Successive stages $(A, B, C, D)$ of the experiment on studying migratory activity of imagoes of Sitophilus granarius 10, 20, 30, 60, and 120 seconds after the start of the experiment.

\section{Results}

In total, using 960 photos, we determined the positions of 320 thou imagoes of Tribolium confusum and Sitophilus granarius. In the control variant of the experiment, $90.0 \%$ of imagoes of Tribolium confusum remained at the distance of up to $4 \mathrm{~cm}$ after $10 \mathrm{sec}$, and at $120 \mathrm{sec}$, there remained $61.8 \%$ (hereinafter the median of each characteristic is described, Fig. 2a). No significant differences compared with the control were recorded for alcohol (Fig. 2b), benzoic acid (Fig. 2c), toluene (Fig. 2d), hydroquinone (Fig. 2e), and phenethyl alcohol (Fig. 2f): at the 120th second of the experiment, $62.0-72.5 \%$ of imagoes of $T$. confusum migrated to the distance of no more than $4 \mathrm{~cm}$. Also, no reliable influence on the migratory activity of imagoes of T. confusum after 10-120 $\mathrm{sec}$ of the experiment was seen for pinene (Fig. 3a), methylparaben (Fig. 3b), kojic acid (Fig. 3c), formic acid (Fig. 3d), isoamyl alcohol (Fig. 3e), and tartaric acid (Fig. 3f): at 120th second, $54.0-68.8 \%$ did not pass $4 \mathrm{~cm}$ distance. Influence of flavoring compounds on migratory activity of imagoes of T. confusum 120 sec after the beginning of the experiment was also weak for glycine (Fig. 4a), succinic acid (Fig. 4b), stearic acid (Fig. 4c), and EDTA (Fig. $4 \mathrm{~d}$ ): $4 \mathrm{~cm}$ distance was passed by $59.0-71.0 \%$.

The moving activity of Sitophilus granarius was much higher than that of Tribolium confusum both in the control and the variants with influence of aromatic compounds (Figs 5-7). In the control variant of the experiment (Fig. 5a), imagoes of Sitophilus granarius migrated no farther than $4 \mathrm{~cm}$; the migratory activity after 10, 20, 30, 60, and $120 \mathrm{sec}$ after the beginning of the experiment equaled $72.9,41.4,28.5,14.4$, and $11.0 \%$, respectively (Fig. 5a). Interestingly, under the influence of benzyl alcohol (Fig. 5b), at the 120th second, a reliably higher number of beetles remained near the source of aroma (67.0\%). Less manifested effects compared with the control were shown for benzoic acid (Fig. 5c) and toluene (Fig. $5 \mathrm{~d}$ ): at the 120th second, 29.2 and $36.3 \%$ of beetles of $S$. granarius remained near the aroma source. Compared with the control, the strongest attractant effects were displayed by hy- 

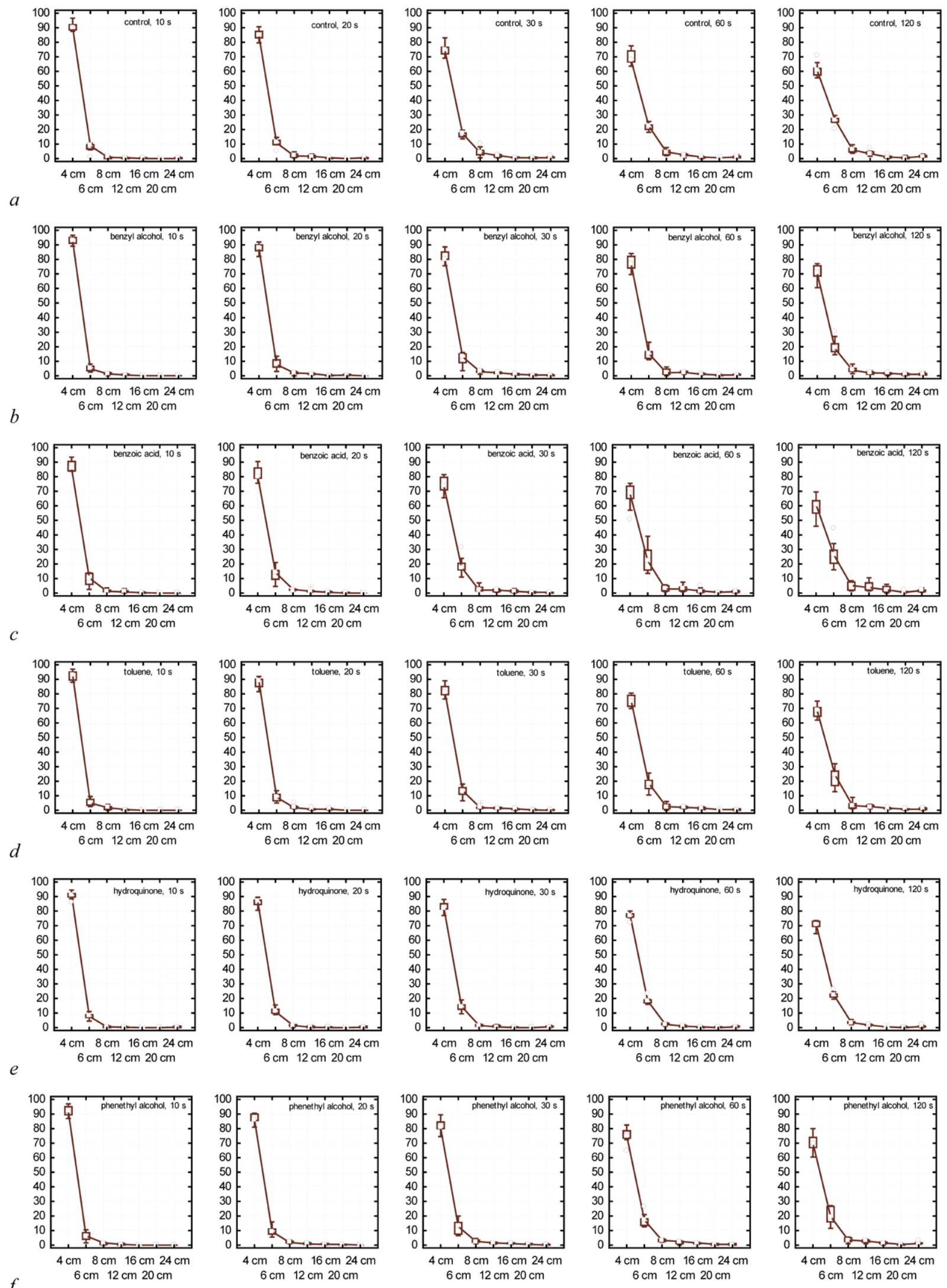

Fig. 2. The effects of flavoring compounds on migratory activity of imagoes of Tribolium confusum 10, 20, 30, 60, and 120 sec after the start of the experiment: control $(a)$, benzyl alcohol $(b)$, benzoic acid $(c)$, toluene $(d)$, hydroquinone $(e)$, and phenethyl alcohol $(f)$; on the abscissa axis-distance traveled by the beetles $(\mathrm{cm})$; on the ordinate axis-share $(\%)$ of the total amount of beetles that are at this distance at a particular moment. 

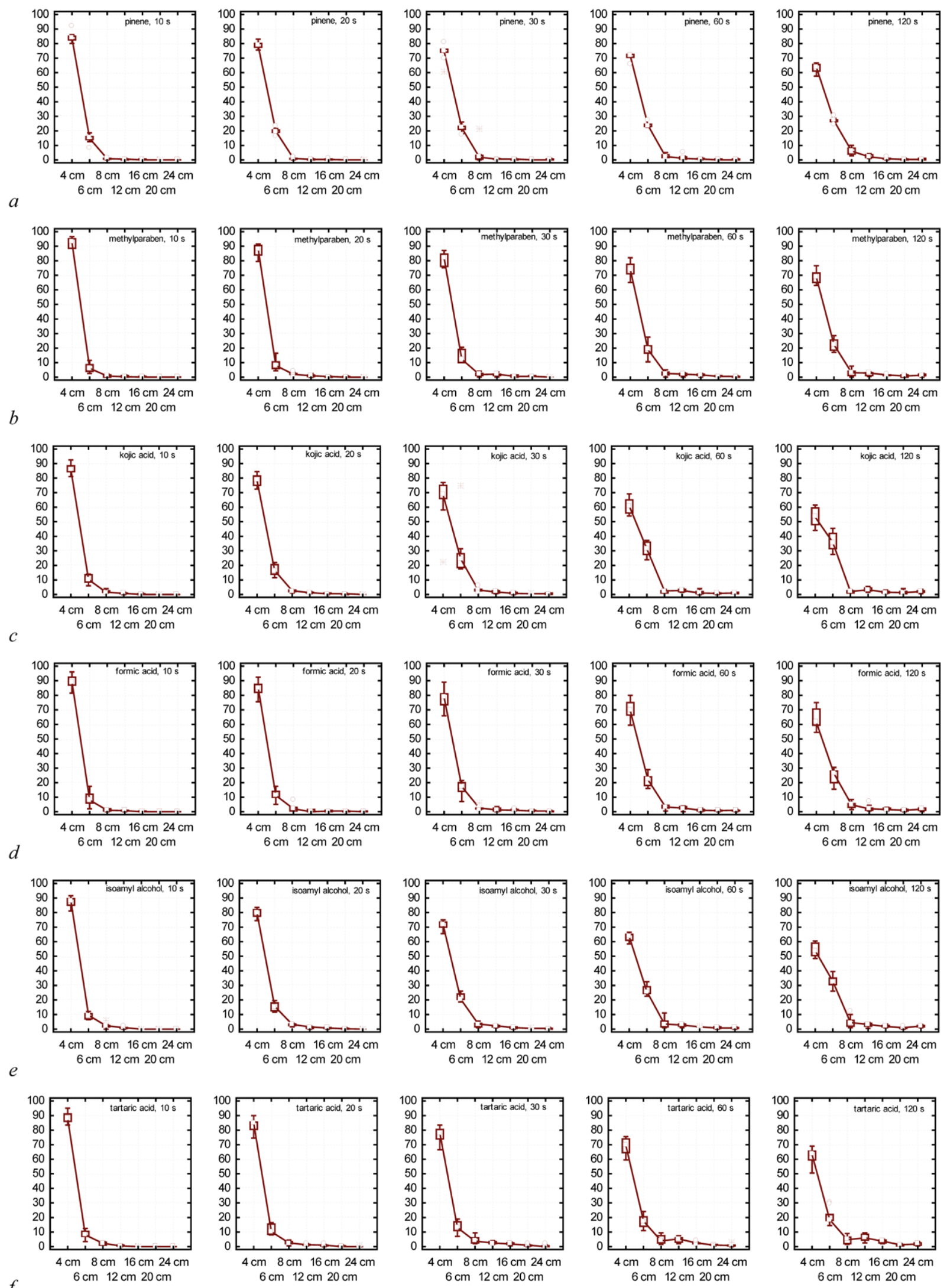

Fig. 3. Influence of flavoring compounds on migratory activity of imagoes of Tribolium confusum 10, 20, 30, 60, and 120 sec after the start of the experiment: pinene $(a)$, methylparaben $(b)$, kojic acid $(c)$, formic acid $(d)$, isoamyl alcohol $(e)$, and tartaric acid $(f)$; on the abscissa axis-distance traveled by the beetles $(\mathrm{cm})$; on the ordinate axis-share $(\%)$ of the total number of beetles at a particular distance at a particular moment. 

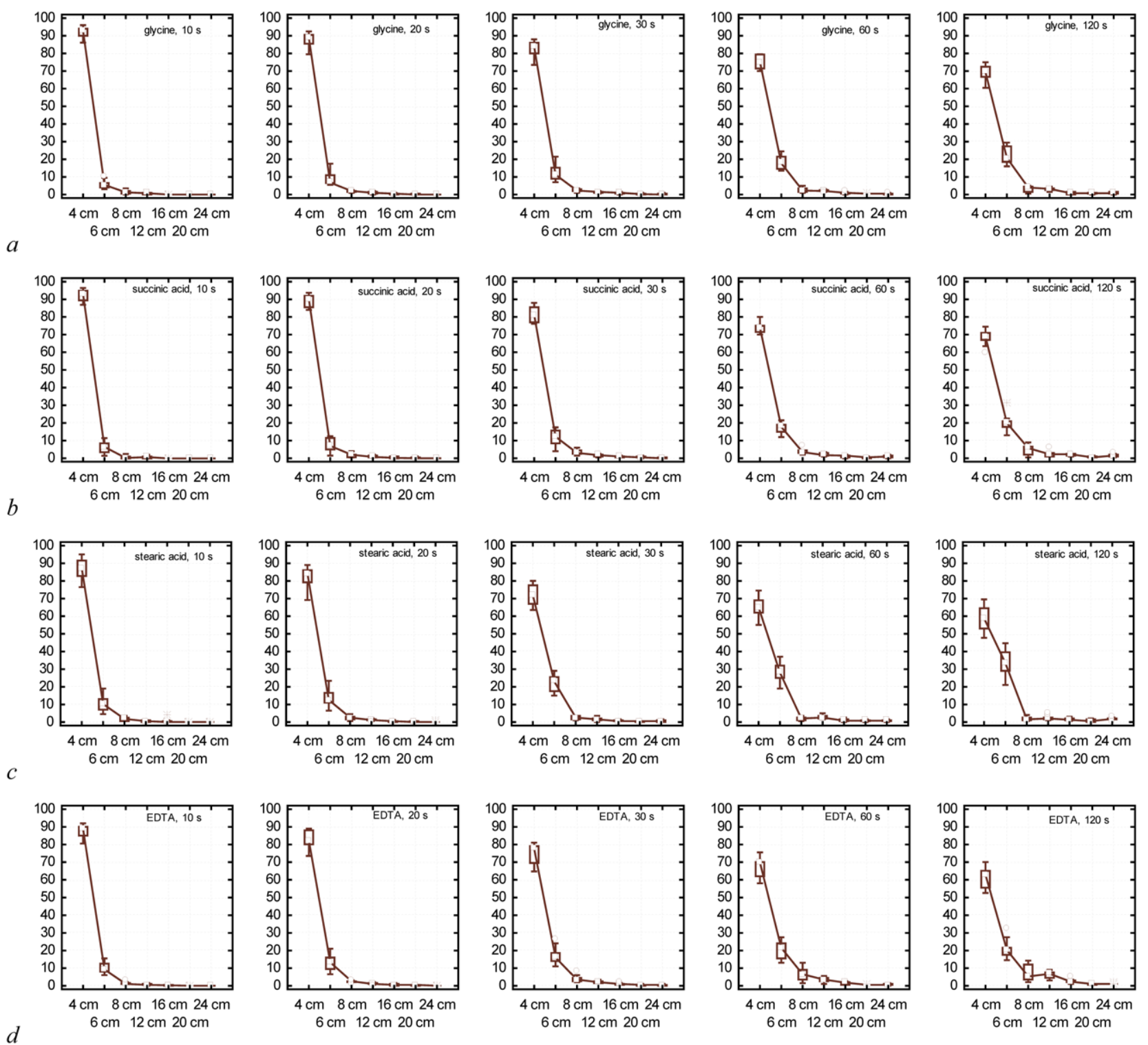

Fig. 4. Influence of flavoring compounds on migratory activity of imagoes of Tribolium confusum 10, 20, 30, 60, and 120 sec after the start of the experiment: glycine $(a)$, succinic acid $(b)$, stearic acid $(c)$, and EDTA $(d)$; on the abscissa axis-distance traveled by the beetles $(\mathrm{cm})$; on the ordinate axis-share (\%) of the total number of beetles at a particular distance at a particular moment.

droquinone (Fig. 5e) and phenethyl alcohol (Fig. 5f): two minutes after the beginning of the experiment, 66.8 and $60.5 \%$ of imagoes of $S$. granarius correspondingly concentrated at the initial point. A slight difference in the migratory activity compared with the control was observed for pinene-the distance of less than $4 \mathrm{~cm}$ was passed for $120 \mathrm{sec}$, 1.9\% (Fig. 6a); methylparaben-35.0\% (Fig. 6b); kojic acid-5.5\% (Fig. 6c); formic acid-23.7\% (Fig. 6d); isoamyl alcohol-2.4\% (Fig. 6e), and tartaric acid-16.2\% (Fig. 6f). A well-expressed attractant effect was observed for glycine (Fig. $7 \mathrm{a}$ ), and $49.5 \%$ of specimens of $S$. granarius remained at a minimal distance from the aroma source. Weaker attractant effects were exerted by EDTA-37.8\% (Fig. 7d) and succinic acid-31.2\% (Fig. 7b). Effect of stearic acid reliably did not differ from the control, leaving only $4.6 \%$ of beetles of $S$. granarius at a minimal distance after $120 \mathrm{sec}$ of the experiment (Fig. 7c).

\section{Discussion}

Currently, one of the main ways to exterminate pests of grains and grain products is phosphine treatment. However, resistance to phosphine is becoming more and more common. In 22 Brazilian populations of Sitophilus zeamais (Pimentel et al., 2009), the resistance ratios at the $\mathrm{LC}_{50}$ among adults ranged 1.1- to 86.6fold. Higher levels of resistance to phosphine were observed in populations with lower respiration rates. Storage pests continuously evolve, and therefore the continuous search of plant and chemical preparations is needed for limiting their numbers.

People have been using botanical insecticides to protect their crops since the beginning of agriculture (Grdiša, Gršić, 2013). The most important botanical insecticide is considered to be pyrethrin, a secondary metabolite of Tanacetum cinerariifolium; 

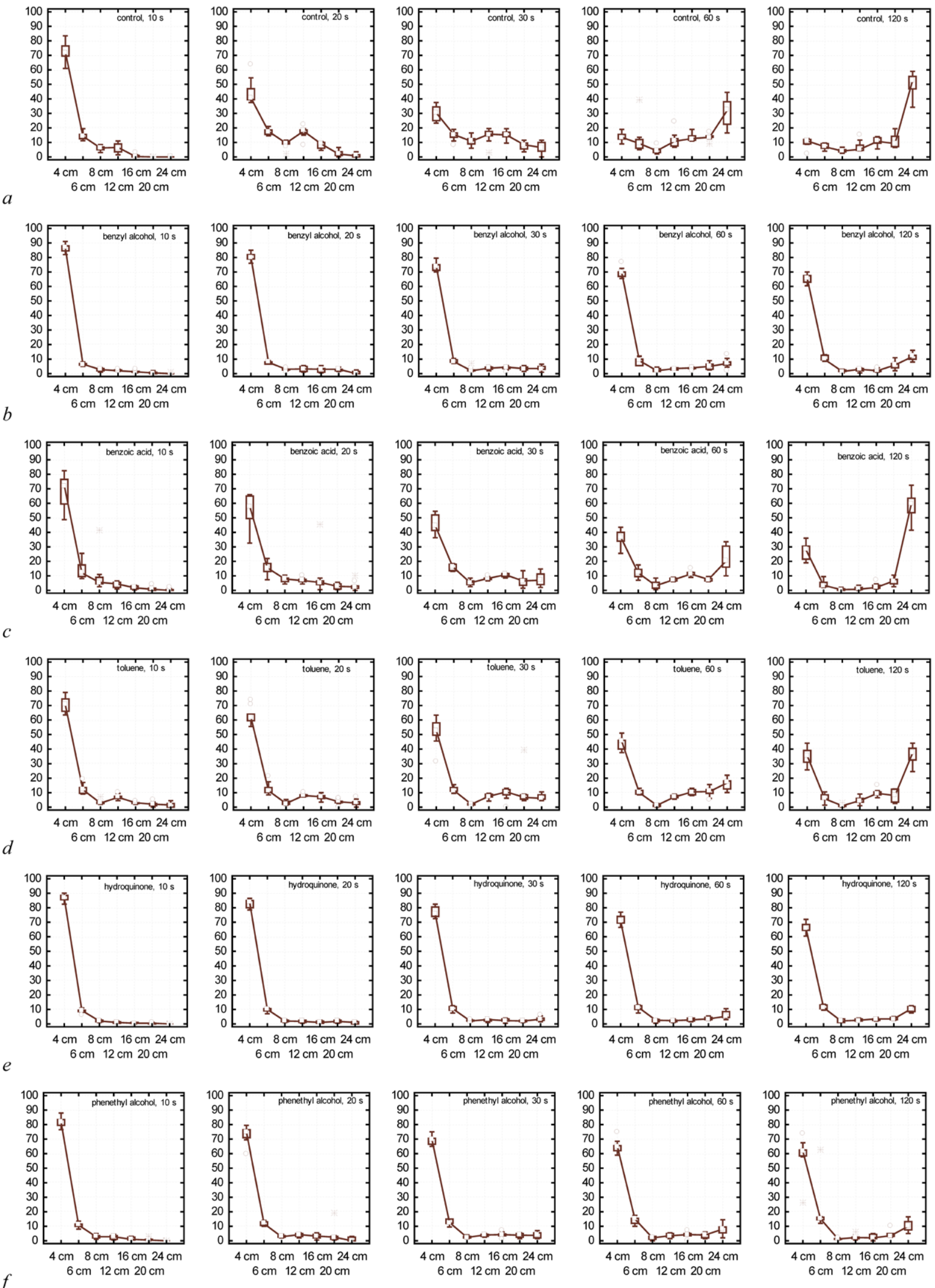

Fig. 5. Effects of flavoring compounds on migratory activity of imagoes of Sitophilus granarius 10, 20, 30, 60, and 120 sec after the start of the experiment: control $(a)$, benzyl alcohol $(b)$, benzoic acid $(c)$, toluene $(d)$, hydroquinone $(e)$, and phenethyl alcohol $(f)$; on the abscissa axis-distance traveled by the beetles $(\mathrm{cm})$; on the ordinate axis-share (\%) of the total number of beetles at a particular distance at a particular moment. 

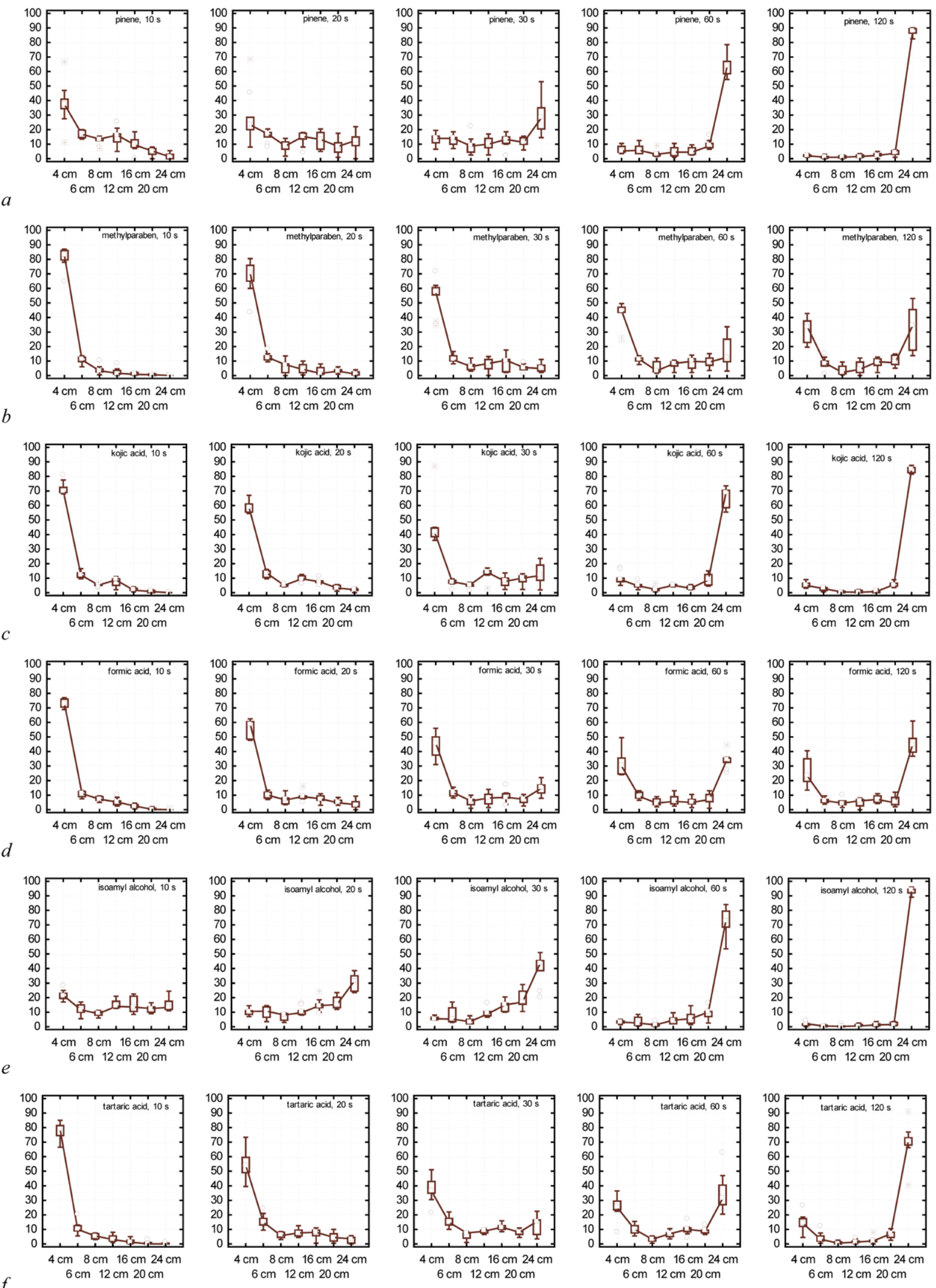

Fig. 6. Effects of flavoring compounds on migratory activity of imagoes of Sitophilus granarius 10,20, 30, 60, and 120 sec after the beginning of the experiment: pinene $(a)$, methylparaben $(b)$, kojic acid $(c)$, formic acid $(d)$, isoamyl alcohol $(e)$, and tartaric acid $(f)$; on the abscissa axis-distance traveled by the beetles $(\mathrm{cm})$; on the ordinate axis-share $(\%)$ of the total number of beetles that were at a particular distance at a particular moment. 

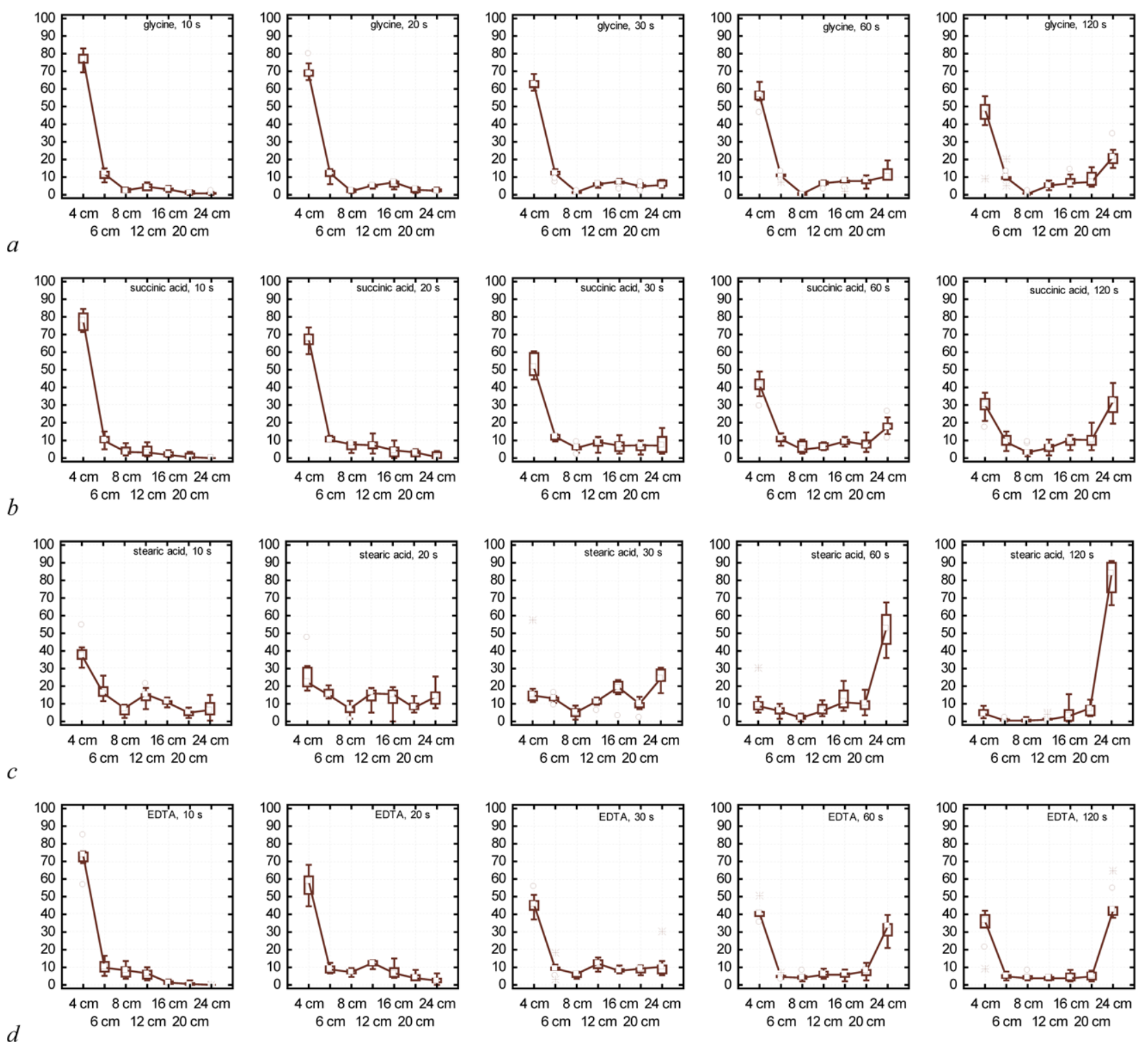

Fig. 7. Effects of flavoring compounds on migratory activity of Sitophilus granarius через 10,20,30,60, and 120 sec after the beginning of the experiment: glycine $(a)$, succinic acid $(b)$, stearic acid $(c)$, and EDTA $(d)$; on the abscissa axis-distance traveled by the beetles $(\mathrm{cm})$; on the ordinate axis-share (\%) of the total number of beetles that were at a particular distance at a particular moment of time.

some others are essential oil-based insecticides-rotenone, quassia, ryania, and sabadilla (Grdiša, Gršić, 2013). Unfortunately, none of these insecticides are broadly used for pest control, but nonetheless they are recognized by organic farmers in industrialized countries. Botanicals are generally considered to constitute little danger to the environment or human health (Isman, 2006). Currently, in industrialized countries, only a small number of botanicals are used in agriculture, and there are some possibilities of developing new botanical products in the future. Plant substances that provoked changes in anthropod behavior have not achieved notable success on the market (Isman, 2006). Production of organic food is the sphere in which botanical insecticides are used best. Nonetheless, they may also provide protection to food products during production and the postharvest period in developing countries (Isman, 2006), where the degree of use of pesticides is high. At the same time, extracts from local plants may also be efficient in crop protection, used either alone or combined with conventional insecticides in lower amounts (Isman, 2008).

As synthetic pesticides have proved harmful to health, the environment, and organisms, the search for alternative means of pest control is becoming more relevant (Langraf et al., 2019, $2020 \mathrm{a}, \mathrm{b})$. The insect attractants are an important bond between these systems (Hao et al., 1996). The effects of synthetic food additives on storage pests are studied insufficiently (Martynov, Brygadyrenko, 2017, 2018). Most often, the behavior of the insect, change in its body weight, or death is understood as response reactions to the substances. The essential oils have been broadly 
applied for their antiparasitic (Boyko, Brygadyrenko, 2016, 2017, 2018, 2019, 2020, 2021), bactericidal, fungicidal, antiviral, and insecticidal actions (Pérez et al., 2010; Brygadyrenko, Nazimov, 2015; Martynov et al., 2019). Beetle pests were observed to be affected by essential oils from 30 families, the highest number of species belongs to the following families: 22 species belong to the family Lamiaceae, 17 to Asteraceae, and 10 to Myrtaceae (Pérez et al., 2010).

Notable effect on the mating of pest moths Spodoptera littoralis Boisduval (Lepidoptera, Noctuidae) and Grapholita molesta (Busck) (Lepidoptera, Tortricidae) was exerted by thyme oil (its constituents thymol, carvacrol, and p-cymene), particularly its major component thymol, which decreased the number of $G$. molesta and Spodoptera littoralis males landing on the pheromone source (López et al., 2021). Singh and Upadhyay (1993) report the susceptibility of $S$. oryzae to volatile oils of Eucalyptus, Japanese mint, dill, turpentine, and citronella. Out of 28 tested essential oils, the greatest impacts were displayed by cinnamon oil, both in contact/residual and fumigant bioassays, significantly inhibiting behavioral activity of S. zeamais (Yang et al., 2020). The studies (Yang et al., 2020) also revealed that S. zeamais was affected the most by such components as cinnamaldehyde in cinnamon oil and terpinen-4-ol in tea tree and marjoram oils.

The study of fumigant bioactivity of five Citrus essential oils against Tribolium confusum (Campolo et al., 2013) demonstrated that in laboratory conditions, in low concentrations, these essential oils may efficiently decrease the numbers of storage pests. However, while dust, flour, or grains are present, their effectiveness sharply decreases (Campolo et al., 2013).

Notable repellent activity against $T$. confusum was displayed by essential oils from Jasminum officinale and Thuja occidentalis in the concentration of $0.48 \mathrm{~mL} / \mathrm{cm}^{2}$ (Martynov et al., 2019). In turn, essential oils from Zingiber officinale and Cedrus atlantica had a luring effect on the insect. Repellent properties were exhibited by essential oils from Rosmarinus officinalis, Melaleuca alternifolia, Lavandula angustifolia, and Cinnamomum verum, and essential oils of Juniperus communis and Citrus sinensis attracted the pest (Martynov et al., 2019).

Essential oil of Lavandula angustifolia Miller contains 53 components, the main being linalool (23.8\%), 1,8-cineole (12.0\%), borneol (10.7\%), terpinen-4-ol (10.0\%), linalyl acetate (6.9\%), (E)- $\beta$-ocimene (6.2\%), (E)- $\beta$-farnesene (3.5\%), and camphor $(2.8 \%)$ (Germinara et al., 2017). This essential oil was notably fumigant-toxic to Sitophilus granarius, but the effect was lower in the presence of wheat grains. Germinara et al. (2017) reported that the essential oil from Lavandula angustifolia had no significant effect on feeding activity, growth rate, food consumption, and food utilization of this beetle. Whether oils may be used as repellents for storage pests was discussed by Zohry et al. (2020). According to the mean repellent effect, the tested oils may be presented as follows (ranked starting from the strongest): Cinnamomum zeylanicum (96.2\%), Allium sativum (91.3\%), Dianthus caryophyllus (90.4\%), Ocimum basilicum (87.0\%), Mentha piperita (79.3\%), Rosmarinus officinalis (74.5\%), Citrus sinensis (53.5\%), Sesamum indicum (13.1\%), and Nigella sativa (11.2\%) (Zohry et al., 2020). The results demonstrate that the repellent activity of the oils depended on the duration of exposure.

Essential oil from leaves of Schinus areira (Anacardiaceae) was seen to have a repellent impact on Tribolium castaneum, while the essential oil from its fruit attracted the insect (Descamps et al., 2011). Fumigant activity of essential oil of mugwort, Artemisia vulgaris, against Tribolium castaneum was studied by Wang et al. (2006): $8.0 \mu \mathrm{L} / \mathrm{mL}$ concentration killed $100 \%$ of the adults. Insecticidal effect of extract of Cinnamomum aromaticum Nees was determined against Tribolium castaneum (Herbst) and Sitophilus zeamais Motsch (Huang, Ho, 1998). Cinnamaldehyde was observed to be more fumigant-toxic to Tribolium castaneum than Sitophiluis zeamais. Due to the combinatory effect of its fumigant and antifeedant properties, cinnamaldehyde is potentially useful for the protection of grain (Huang, Ho, 1998).

The main components extracted from the roots of Valeriana officinalis L. using hydrodistillation were bornyl acetate (48.2\%) and camphene (13.8\%) (Feng et al., 2019). Bornyl acetate and camphene were significantly fumigant and contact-toxic to Tribolium castaneum $\left(\mathrm{LC}_{50}>126.3,4.1 \mathrm{mg} / \mathrm{L}\right.$ air, and $\mathrm{LD}_{50}=66.0$, $21.6 \mathrm{~g} /$ adult). Bornyl acetate and camphene exerted moderate repellent action toward T. castaneum. Organic extracts from 13 species of plants exhibited repellent properties against Sitophilus zeamais (Han et al., 2017). A study on the effects of essential oil from hop (Humulus lupulus L.) as well as its major components against Sitophilus granarius was performed by Paventi et al. (2020). The impact on the pest was taken by $\alpha$-humulene, $\beta$-myrcene, and $\beta$-caryophyllene-the three major constituents of the oil-equaling, respectively, $\mathrm{LD}_{50}-41.9,75.9$, and $138.5 \mu \mathrm{g} /$ adult. Hop essential oil and terpenes were sensed by insect antennae and exhibited repellent activity (Paventi et al., 2020).

Experiments similar to ours on synthetic aroma substances were performed by Germinara et al. (2008). They tested the influence of 20 individual volatiles (aliphatic alcohols, aldehydes, ketones, and aromatics) on S. granarius in a two-choice pitfall olfactometer, using the aggregation pheromone and propionic acid as the attractant and repellent controls, correspondingly. The studies by Germinara et al. (2008) revealed that adult S. granarius have various behavioral reactions to individual cereal volatiles, which change depending on the concentration of the substance: behavior of beetles is determined by the overall impact of all negative and positive stimuli on them. For example, three substances were found to attract beetles in lower concentration and repel in higher concentrations (Germinara et al., 2008).

It is known that the odors associated with grains on which the weevils feed, mate, and deposit eggs are attractant (Stuhl, 2019). Powerful fumigant-toxic impacts on Tribolium castaneum were exhibited by three monoterpenoids: camphor, camphene, and limonene $\left(\mathrm{LC}_{50}<2.3,6.2\right.$, and $6.2 \mathrm{mg} / \mathrm{L}$ air) (Chen et al., 2018). Essential oil from Amomum villosum Lour. and its four constituents (bornyl acetate [51.6\%], camphor [19.8\%], camphene [8.9\%], and limonene [6.2\%]) showed repellent effect on Tribolium castaneum at high concentration $\left(78.6 \mathrm{~nL} / \mathrm{cm}^{2}\right)$, although decreased concentration attracted the beetle (Chen et al., 2018).

Linalool and $\beta$-pinene are natural components of the essential oils of many plant species worldwide (Pajaro-Castro et al., 2017). Compared with linalool, $\beta$-pinene demonstrated greater repellent efficacy toward T. castaneum, as well as causing changes in genes that take part in neuronal transmission. Linalool and $\beta$-pinene provoked overexpression of $\mathrm{Hiscl} 2$ gene in adult insects, and $\beta$-pinene also caused the overexpression of Grd and the Ace1 gene. Thus, beetles exposed to these flavoring compounds undergo changes in the rates of synthesis of informational RNA and an increase in the rates of synthesis of proteins - the products of the activity of these genes. 
Male adults of T. castaneum were observed to biosynthesize aggregation pheromone 4,8-dimethyldecanal (Dissanayaka et al., 2020a). Aromatic substances take a strong effect only during a short time: the highest number of $T$. castaneum specimens was lured into traps from the distance of $30 \mathrm{~cm}$ during the first $4 \mathrm{~h}$ of exposure, amounting to $40.5 \%$ of the total number of beetles, and in $24 \mathrm{~h}$, the total share of the lured beetles was $45.5 \%$ (Dissanayaka et al., 2020a). During the experiment with all the pheromone concentrations, the highest trapping percentage for T. castaneum was observed when the beetles were released at the distance of 30-60 cm from the pheromone. The traps containing a combination of pheromone (4,8-dimethyldecanal) and kairomone (food oil) lured adults of $T$. castaneum better than the ones only containing the pheromone (Dissanayaka et al., 2020b). The beetles of T. castaneum were lured to the pheromone/kairomone- or pheromone-containing traps best (e.g., more encountered traps, more remained in observation zone, more time was spent on the treatment side, and decreased speed and increased turn angle) in the conditions of air movement, whereas in the still air, kairomone alone and all attractants provoked the beetles to no significant response (Campbell, 2012). Even when using the best combination of attractants, as well as airflow, the average number of trapped T. castaneum individuals accounted for only 40\% (Campbell, 2012).

The high efficiency of sulfuryl fluoride and methyl bromide fumigations on populations of Tribolium spp. in UK flour mills was experimentally proven (Small, 2007).

Limonene is traditionally used for flavoring, fragrance, and as green solvent but is now being also actively applied as a solvent for chemical extraction of natural products and an active agent in products (Ciriminna et al., 2014). The fumigant and repellent properties of limonene (a common plant monoterpene) in relation to $T$. confusum were also surveyed by Malacrinò et al. (2016): concentration of $85 \mathrm{mg} / \mathrm{L}$ air demonstrated 100\% efficacy.

The experiment using correlation methods demonstrated that Prostephanus truncatus (Horn) beetles (Coleoptera, Bostrichidae) were lured simultaneously by the combination of heightened concentration of palmitic acid and large-sized wheat grain (Ngom, Sembène, 2020).

Benzaldehyde was found in the volatiles of ife-brown and black-eyed cowpea, Vigna unguiculata (L. Walp), the greater amount being given off by ife-brown cowpea. Beetles of Callosobruchus maculatus (Coleoptera, Chrysomelidae) were lured by ripened pods of ife-brown cowpea, the most attractive part of the plant (Ajayi et al., 2018).

Phillips et al. (1993) determined that Sitophilus oryzae was lured by fresh grain volatiles valeraldehyde, maltol, and vanillin in various concentrations, though Tribolium castaneum was indifferent to all the concentrations of these three compounds. Three grain volatiles-valeraldehyde, maltol, and vanillin-combined with the synthetic pheromone sitophinone had the greater luring effect on Sitophilus oryzae than either the pheromone on its own or the tripartite grain volatile mix (Phillips et al., 1993). Newly developed sachet repellent containing 2\% allyl mercaptan displayed notable repellent action toward S. oryzae; and similar, nonetheless weaker, repellent properties were seen for allyl disulfide (Chang et al., 2017).

Collins et al. (2004) proposed using a Y-tube olfactometer for behavioral biotest with S. granarius. The authors indicate that the optimum conditions for screening potential attractants in relation to all three species were $20^{\circ} \mathrm{C}$ and $50 \%$ relative humidity, the duration of bioassay equaling $1 \mathrm{~h}$. These researchers also observed the higher repellent effect in higher temperatures (from 15 to $20^{\circ} \mathrm{C}$ ) (Collins et al., 2004; Piesik, Wenda-Piesik, 2015).

The moving activity of storage pests is a result of the interaction of many factors, some of which are hard to analyze. For instance, traps with 10 seeds damaged by $S$. oryzae were significantly more attractive than the traps with oil lure or control traps for S. oryzae but not for Tribolium confusum (Athanassiou et al., 2006). Traps with 20 live adults of $S$. oryzae were notably more attractive than traps with 20 dead adults of Sitophilus oryzae or the control traps (Athanassiou et al., 2006).

Pheromone traps are broadly employed in the practice of counting of and combat against the most harmful storage pests (Hodges et al., 1998). A single pitfall bioassay is considered a standard test for the response of small beetle pests to potential attractants (Morgan et al., 1998). For the assessment of numbers of $S$. granarius, synthetic aggregation pheromone sitophilate is used (Plarre, 1996): the aggregation pheromone was seen to arrest rather than the lure. Collins et al. (2007) studied the response of $S$. granarius to the attractant components of a carob-peanut extract. The authors proposed various compounds (E-2-nonenal, 4-ethylacetophenone, 2-phenylethanol, hexanoic acid, and E-3-octen-2-one) to be used as components of bait that contains several active agents and is active against several species of storage pests. Responses of S. zeamais and S. oryzae to 4S, $5 \mathrm{R}$-sitophinone were observed when exposed to concentrations as low as $0.025 \mathrm{ng}$. The significant response of $S$. granarius was recorded during exposure to $50 \mathrm{ng}$ concentration of $4 \mathrm{~S}$, 5R-sitophinone (Wakefield et al., 2005). The impact of pheromone and volatiles from kibbled carob used in combination decreased with an increase in the age of insect. A field experiment on trapping and monitoring the activity of insects related to stored products in the traditional African granaries (Ukeh et al., 2008) revealed that pheromone traps lure males and females of some species to a different degree.

Aggregation pheromones of Tribolium confusum are used commercially to monitor this beetle, though its efficiency is doubtful and the application of them may be inadequate (Hori et al., 2019). At the same time, the beetles were notably lured by wood odors of Castanea crenata, Magnolia obovata, Paulownia tomentosa, Prunus jamasakura, and Zelkova serrata. The luring effect of these wood odors was also greater compared with the odors of the food these beetles typically eat (Hori et al., 2019).

Imagoes of Tribolium castaneum were tested for attraction to traps with or without airflow and the pheromone either alone or in combination with kairomone (Sajeewani et al., 2020). Without using the fans, three to five times more beetles were captured in the newly designed traps with pheromone alone as compared with the status quo trap.

The main sex pheromone for Sitophilus oryzae and S. zeamais is (4S, 5R)-5-hydroxy-4-methyl-3-heptanone, and for Tribolium castaneum and T. confusum, it is (4R,8R)-dimethyldecanal (Levinson, Levinson, 1995).

Storage pests are often monitored using food attractants and pheromones (Hori et al., 2019). Traps are used to monitor insect pests in stored food habitats, and records of trapped insects may be used for decision-making in pest control programs (Doud, Phillips, 2020). Pheromone traps for various species of 
beetle pests of grains and grain products should differ not only by the composition of pheromones but also by their construction (Doud, Phillips, 2020): they should be protected from dust and be convenient for trapping beetles that move at different rates. According to the research (Germinara et al., 2008), adult granary weevils respond behaviorally to a broad spectrum of cereal volatiles, and these responses vary depending on concentration (Germinara et al., 2008).

The efficiency against Sitophilus granarius spinetoram exerted by the tested commodities varied (Vassilakos et al., 2015): higher mortality was observed in hard wheat than the other grains, and the least mortality occurred in maize, oats, and soft wheat.

Due to the synergism of food odors and pheromones, more efficient traps may be developed to control insect pests (Phillips et al., 1993).

Competitive experiments applying LED at $390 \mathrm{~nm}$ dominant wavelength led to capturing $20 \%$ of released Tribolium castaneum beetles compared with $1 \%$ caught using only the aggregation pheromone (Duehl et al., 2011). Combining LEDs with commercial chemical lures helped to capture even more beetles. After a multiattractant lure (a mixture of natural plant extracts) had been introduced to the perforated traps (pitfall lure), notably more storage cereal-infesting coleopterans were caught. Significantly more adults were found in the traps than with the samples for T. castaneum, $T$. confusum in Greece (Athanassiou et al., 2002). Pheromone traps used for monitoring and mass trapping of T. confusum in Vietnam were the subject of discussion in the research by Hao et al. (1996).

A significant cause of insect invasion is growing international trade, which allows beetles to travel around the globe in shipping containers. Sticky traps with light inside shipping containers were effective against lepidopterans and dipterans but not against Sitophilus zeamais and therefore need improvement. Coleopterans can escape from the traps and so are infrequently caught.

\section{Conclusion}

Pests continuously change the composition of their populations, and some individuals become resistant to certain attractants or repellents, and the progeny of these resistant individuals gain a selective advantage in the next generations, entailing damage to the yield collected by people. Therefore, it is necessary to seek new methods that limit the distribution of storage pests. In our laboratory experiment, we observed no reliable impact of 15 tested aromatic substances (benzyl alcohol, benzoic acid, toluene, hydroquinone, phenethyl alcohol, pinene, methylparaben, kojic acid, formic acid, isoamyl alcohol, tartaric acid, glycine, succinic acid, stearic acid, and EDTA) on the moving activity of Tribolium confusum.

The moving activity of Sitophilus granarius significantly decreased (attractant effect on imagoes accounted for $11.0 \%$ compared with the control, manifested at the 120th second of the experiment) during the exposure to the following substances: $67.0 \%$ of the beetles stayed at minimum distance from the aroma source during exposure to benzyl alcohol, $66.8 \%$ to hydroquinone, $60.5 \%$ to phenethyl alcohol, $49.5 \%$ to glycine, $37.8 \%$ to EDTA, $36.3 \%$ to toluene, $35.0 \%$ to methylparaben, $31.2 \%$ to succinic acid, $29.2 \%$ to benzoic acid, and $23.7 \%$ while exposed to formic acid. The other tested aromatic substances (benzyl alcohol, pinene, kojic acid, isoamyl alcohol, tartaric acid, and stearic acid) had no effect on migratory activity of S. granarius.
The obtained results allow us to recommend benzyl alcohol, hydroquinone, phenethyl alcohol, and glycine as potential attractants of S. granarius for use on private farms, in storages, and in grain processing facilities. These substances may be used as components of pheromone mixtures for the assessment of populations of $S$. granarius in grain storages.

\section{References}

Adamski, Z., Bufo, S.A., Chowański, S., Falabella, P., Lubawy, J., Marciniak, P., Pacholska-Bogalska, J., Salvia, R., Scrano, L., Słocińska, M., Spochacz, M., Szymczak, M., Urbański, A., Walkowiak-Nowicka, K. \& Rosiński G. (2019). Beetles as model organisms in physiological, biomedical and environmental studies - a review. Frontiers in Physiology, 10, 319. DOI: 10.3389/fphys.2019.00319.

Ajayi, O.E., Morawo, T.O. \& Fadamiro H.Y. (2018). Preference of flight morph of Callosobruchus maculatus (Coleoptera: Chrysomelidae) for three plant legumes. International Journal of Tropical Insect Science, 38(4), 362-372. DOI: 10.1017/s1742758418000152.

Athanassiou, C.G., Kavallieratos, N.G., Eliopoulos, P.A., Palyvos, N.E., Casagrande, E. \& Buchelos C.T. (2002). Evaluation of a multi-attractant lure on the capture of several stored-product beetle species. In Advances in stored product protection (pp. 252-257). Proceedings of the 8th International Working Conference on Stored Product Protection, York. DOI: 10.1079/9780851996912.0252.

Athanassiou, C.G., Kavallieratos, N.G. \& Trematerra P. (2006). Responses of Sitophilus oryzae (Coleoptera: Curculionidae) and Tribolium confusum (Coleoptera: Tenebrionidae) to traps baited with pheromones and food volatiles. Eur. J. Entomol., 103(2), 371-378. DOI: 10.14411/eje.2006.050.

Boyer, S., Zhang, H. \& Lempérière G. (2011). A review of control methods and resistance mechanisms in stored-product insects. Bull. Entomol. Res., 102(2), 213-229. DOI: 10.1017/s0007485311000654.

Boyko, A.A. \& Brygadyrenko V.V. (2016). Influence of water infusion of medicinal plants on larvae of Strongyloides papillosus (Nematoda, Strongyloididae). Visnyk of Dnipropetrovsk University, Biology, Ecology, 24(2), 519-525. DOI: 10.15421/011670.

Boyko, A.A. \& Brygadyrenko V.V. (2017). Changes in the viability of Strongyloides ransomi larvae (Nematoda, Rhabditida) under the influence of synthetic flavourings. Regulatory Mechanisms in Biosystems, 8(1), 36-40. DOI: $10.15421 / 021707$.

Boyko, O.O. \& Brygadyrenko V.V. (2018). The impact of certain flavourings and preservatives on the survivability of larvae of nematodes of Ruminantia. Regulatory Mechanisms in Biosystems, 9(1), 118-123. DOI: $10.15421 / 021817$.

Boyko, O.O. \& Brygadyrenko V.V. (2019). The impact of acids approved for use in foods on the vitality of Haemonchus contortus and Strongyloides papillosus (Nematoda) larvae. Helminthologia, 56(3), 202-210. DOI: 10.2478/helm-2019-0017.

Boyko, O.O. \& Brygadyrenko V.V. (2020). The impact of certain flavourings and preservatives on the survivability of eggs of Ascaris suum and Trichuris suis. Regulatory Mechanisms in Biosystems, 11(2), 344-348. DOI: $10.15421 / 022052$.

Boyko, O. \& Brygadyrenko V. (2021). Nematicidal activity of essential oils of medicinal plants. Folia Oecologica, 48(1), 42-48. DOI: $10.2478 /$ foecol-2021-0005.

Brygadyrenko, V.V. \& Nazimov S.S. (2015). Trophic relations of Opatrum sabulosum (Coleoptera, Tenebrionidae) with leaves of cultivated and uncultivated species of herbaceous plants under laboratory conditions. Zookeys, 481, 57-68. DOI: 10.3897/zookeys.481.7015.

Burnett, C.L., Bergfeld, W.F., Belsito, D.V., Hill, R.A., Klaassen, C.D., Liebler, D.C., Marks, J.G. Jr, Shank, R.C., Slaga, T.J., Snyder, P.W. \& Andersen F.A. (2010). Final report of the safety assessment of kojic acid as used in cosmetics. Int. J. Toxicol., 29, 244S-73. DOI: 10.1177/1091581810385956.

Campbell, J.F. (2012). Attraction of walking Tribolium castaneum adults to traps. J. Stored Prod. Res., 51, 11-22. DOI: 10.1016/j.jspr.2012.06.002.

Campolo, O., Malacrinò, A., Zappalà, L., Laudani, F., Chiera, E., Serra, D., Russo, M. \& Palmeri V. (2014). Fumigant bioactivity of five Citrus essential oils against Tribolium confusum. Phytoparasitica, 42, 223-233. DOI: 10.1007/s12600-013-0355-4. 
Chang, Y., Lee, S.H., Na, J.H., Chang, P.S. \& Han J. (2017). Protection of grain products from Sitophilus oryzae (L.) contamination by anti-insect pest repellent sachet containing allyl mercaptan microcapsule. J. Food Sci. 82(11), 2634-2642. DOI: 10.1111/1750-3841.13931.

Chen, Z., Guo, S., Cao, J., Pang, X., Geng, Z., Wang, Y., Zhang, Z. \& Du S. (2018). Insecticidal and repellent activity of essential oil from Amomum villosum Lour. and its main compounds against two stored-product insects. International Journal of Food Properties, 21(1), 2265-2275. DOI 10.1080/10942912.2018.1508158.

Ciriminna, R., Lomeli-Rodriguez, M., Demma Carà, P., Lopez-Sanchez, J.A \& Pagliaro M. (2014). Limonene: A versatile chemical of the bioeconomy. Chemical Communications, 50(97), 15288-15296. DOI: 10.1039/ c4cc06147k.

Collins, L.E., Wakefield, M.E., Chambers, J. \& Cox P.D. (2004). Progress towards a multi-species lure: Comparison of behavioural bioassay methods for multi-species attractants against three pests of stored grain. J. Stored Prod. Res., 40(3), 341-353. DOI: 10.1016/S0022-474X(03)00028-6.

Collins, L.E., Bryning, G.P., Wakefield, M.E., Chambers, J. \& Cox P.D. (2007). Progress towards a multi-species lure: Identification of components of food volatiles as attractants for three storage beetles. J. Stored Prod. Res., 43(1), 53-63. DOI: 10.1016/j.jspr.2005.10.001.

Collins, L.E., Bryning, G.P., Wakefield, M.E., Chambers, J., Fennah, K. \& Cox P.D. (2008). Effectiveness of a multi-species attractant in two different trap types under practical grain storage conditions. J. Stored Prod. Res., 44(3), 247-257. DOI: 10.1016/j.jspr.2008.01.002.

Daglish, G.J., Nayak, M.K. \& Arthur F.H. (2018). Insect pest management in stored grain. Recent Advances in Stored Product Protection, 3(4), 45-63.

Descamps, L.R., Chopa, C.S. \& Ferrero A.A. (2011). Activity of Schinus areira (Anacardiaceae) essential oils against the grain storage pest Tribolium castaneum. Natural Product Communications, 6(6), 887-891. DOI: 10.1177/1934578x1100600632.

Dissanayaka, D.M.S.K., Sammani, A.M.P. \& Wijayaratne L.K.W. (2020a) Orientation of Tribolium castaneum (Herbst) (Coleoptera: Tenebrionidae) adults at various distances to different concentrations of aggregation pheromone 4, 8-dimethyldecanal. J. Stored Prod. Res., 87, 101631. DOI: $10.1016 /$ j.jspr.2020.101631.

Dissanayaka, D.M.S.K., Sammani, A.M.P., Wijayaratne, L.K.W., Bamunuarachchige, T.C. \& Morrison III. W.R. (2020b). Distance and height of attraction by walking and flying beetles to traps with simultaneous use of the aggregation pheromones from Tribolium castaneum (Herbst) (Coleoptera: Tenebrionidae) and Rhyzopertha dominica (F.) (Coleoptera: Bostrychidae). J. Stored Prod. Res., 89, 101705. DOI: 10.1016/j. jspr.2020.101705.

Doud, C.W. \& Phillips T.W. (2020). Responses of red flour beetle adults, Tribolium castaneum (Coleoptera: Tenebrionidae), and other stored product beetles to different pheromone trap designs. Insects, 11(11), 733 DOI: $10.3390 /$ insects11110733.

Duehl, A.J., Cohnstaedt, L.W., Arbogast, R.T. \& Teal P.E.A. (2011). Evaluating light attraction to increase trap efficiency for Tribolium castaneum (Coleoptera: Tenebrionidae). J. Econ. Entomol., 104(4), 1430-1435. DOI: $10.1603 /$ ec10458.

Feng, Y.X., Wang, Y., Chen, Z.Y., Guo, S.S., You, C.X. \& Du S.S. (2019). Efficacy of bornyl acetate and camphene from Valeriana officinalis essential oil against two storage insects. Environ. Sci. Pollut. Res., 26(16), 1615716165. DOI: 10.1007/s11356-019-05035-y.

Germinara, G.S., De Cristofaro, A. \& Rotundo G. (2008). Behavioral responses of adult Sitophilus granarius to individual cereal volatiles. J. Chem. Ecol., 34(4), 523-529. DOI: 10.1007/s10886-008-9454-y.

Germinara, G.S., Di Stefano, M.G., De Acutis, L., Pati, S., Delfine, S., De Cristofaro, A. \& Rotundo G. (2017). Bioactivities of Lavandula angustifolia essential oil against the stored grain pest Sitophilus granarius. Bulletin of Insectology, 70(1), 129-138.

Grdiša, M. \& Gršić K. (2013). Botanical insecticides in plant protection. Agric. Conspec. Sci., 78(2), 85-93.

Han, G.D., Kum, H.J., Chun, Y.S., Na, J. \& Kim W. (2017). Repellency and attractancy of plant extracts against Plodia interpunctella and Sitophilus zeamais. J. Stored Prod. Res., 74, 33-35. DOI: 10.1016/j.jspr.2017.09.002.

Hao, N.C., Nguyen Cuu Thi Huong Giang Khoa, N.C. \& Son N.T. (1996). Synthesis and application of insect attractants in Vietnam. Resour. Conserv. Recycl., 18, 59-68. DOI: 10.1016/s0921-3449(96)01168-8.
Hodges, R.J., Hall, D.R., Mbugua, J.N. \& Likhayo P.W. (1998). The responses of Prostephanus truncatus (Coleoptera: Bostrichidae) and Sitophilus zeamais (Coleoptera: Curculionidae) to pheromone and synthetic maize volatiles as lures in crevice or flight traps. Bull. Entomol. Res., 88(2), 131-139. DOI: 10.1017/S0007485300025700.

Hori, M., Aoki, Y., Shinoda, K., Chiba, M. \& Sasaki R. (2019). Wood volatiles as attractants of the confused flour beetle, Tribolium confusum (Coleoptera: Tenebrionidae). Scientific Reports, 9(1), 11544. DOI: 10.1038/ s41598-019-48073-9.

Huang, Y. \& Ho S.H. (1998). Toxicity and antifeedant activities of cinnamaldehyde against the grain storage insects, Tribolium castaneum (Herbst) and Sitophilus zeamais Motsch. J. Stored Prod. Res., 34(1), 11-17. DOI 10.1016/s0022-474x(97)00038-6.

Isman, M.B. (2006). Botanical insecticides, deterrents, and repellents in modern agriculture and an increasingly regulated world. Annu. Rev. Entomol., 51, 45-66. DOI: 10.1146/annurev.ento.51.110104.151146.

Isman, M.B. (2008). Botanical insecticides: For richer, for poorer. Pest Manag. Sci., 64(1), 8-11. DOI: 10.1002/ps.1470.

Johnson Jr, W., Heldreth, B., Bergfeld, W.F., Belsito, D.V., Hill, R.A., Klaassen, C.D., Liebler, D.C., Marks Jr, J.G., Shank, R.C., Slaga, T.J., Snyder P.W. \& Andersen F.A. (2016). Safety assessment of formic acid and sodium formate as used in cosmetics. Int. J. Toxicol., 35, 41S-54S. DOI: $10.1177 / 1091581816677716$.

Johnson, W., Bergfeld, W.F., Belsito, D.V., Hill, R.A., Klaassen, C.D., Liebler, D.C., Marks, J.G., Shank, R.C., Slaga, T.J., Snyder, P.W. \& Andersen F.A. (2017). Safety assessment of benzyl alcohol, benzoic acid and its salts, and benzyl benzoate. Int. J. Toxicol., 36, 5S-30S. DOI: 10.1177/1091581817728996.

Langraf, V., Petrovičová, K., David, S., Nozdrovická, J., Petrovič, F. \& Schlarmannová J. (2019). The bioindication evaluation of ground beetles (Coleoptera: Carabidae) in three forest biotopes in the southern part of Central Slovakia. Ekológia (Bratislava), 38(1), 25-36. DOI: 10.2478/ eko-2019-0003.

Langraf, V., David, S., Babosová, R., Petrovičová, K. \& Schlarmannová J. (2020a). Change of ellipsoid biovolume (EV) of ground beetles (Coleoptera, Carabidae) along an urban-suburban-rural gradient of Central Slovakia. Diversity, 12(12), 475. DOI: 10.3390/d12120475.

Langraf, V., Petrovičová, K., David, S., Svoradová, A. \& Schlarmannová J. (2020b). Prediction of ecological importance of carabidae biotopes using community index of the ground beetles (Iks) in the southern part of Central Slovakia. Applied Ecology and Environmental Research, 18(1), 1197-1210. DOI: 10.15666/aeer/1801_11971210.

Levinson, A. \& Levinson H. (1995). Reflections on structure and function of pheromone glands in storage insect species. Anzeiger fur Schadlingskunde Pflanzenschutz Umweltschutz, 68(5), 99-118. DOI: 10.1007/ BF01906539.

Lieber, M.A. (1988). Final report on the safety assessment of amyl acetate and isoamyl acetate. Journal of the American College of Toxicology, 7(6), 705-719. DOI: 10.3109/10915818809078708.

López, S., Domínguez, A., Guerrero, Á. \& Quero C. (2021). Inhibitory effect of thymol on pheromone-mediated attraction in two pest moth species. Scientific Reports, 11(1), 1223. DOI: 10.1038/s41598-020-79550-1.

Malacrinò, A., Campolo, O., Laudani, F. \& Palmeri V. (2016). Fumigant and repellent activity of limonene enantiomers against Tribolium confusum du Val. Neotrop. Entomol., 45(5), 597-603. DOI: 10.1007/s13744-0160402-1.

Marchioro, M., Battisti, A. \& Faccoli M. (2020). Light traps in shipping containers: A new tool for the early detection of insect alien species. J. Econ. Entomol., 113(4), 1718-1724. DOI: 10.1093/jee/toaa098.

Martynov, V.O. \& Brygadyrenko V.V. (2017). The influence of synthetic food additives and surfactants on the body weight of larvae of Tenebrio molitor (Coleoptera, Tenebrionidae). Biosystems Diversity, 25(3), 236242. DOI: $10.15421 / 011736$

Martynov, V.O. \& Brygadyrenko V.V. (2018). The impact of some inorganic substances on change in body mass of Tenebrio molitor (Coleoptera, Tenebrionidae) larvae in a laboratory experiment. Folia Oecologica, 45(1), 24-32. DOI: 10.2478/foecol-2018-0003.

Martynov, V.O., Titov, O.G., Kolombar, T.M. \& Brygadyrenko V.V. (2019). Influence of essential oils of plants on the migration activity of Tribolium confusum (Coleoptera, Tenebrionidae). Biosystems Diversity, 27(2), 177-185. DOI: 10.15421/011924. 
Morgan, C., Sherington, J., Gudrups, I. \& Bowden N.S. (1998). The assessment of potential attractants to beetle pests: Improvements to laboratory pitfall bioassay methods. J. Stored Prod. Res., 34(1), 59-74.

Ngom, D. \& Sembène M. (2020). Varietal-hosts attractance and repellence to larger grain borer, Prostephanus truncatus (Horn) (Coleoptera Bostrichidae) and role played by grains morphophysical and biochemical characteristics. International Journal of Tropical Insect Science, 40(4), 877-885. DOI: 10.1007/s42690-020-00145-4.

Pajaro-Castro, N., Caballero-Gallardo, K. \& Olivero-Verbel J. (2017). Neurotoxic effects of linalool and $\beta$-pinene on Tribolium castaneum Herbst. Molecules, 22(12), 2052. DOI: 10.3390/molecules22122052.

Paventi, G., de Acutis, L., De Cristofaro, A., Pistillo, M., Germinara, G.S. \& Rotundo G. (2020). Biological activity of Humulus lupulus (L.) essential oil and its main components against Sitophilus granarius (L.). Biomolecules, 10(8), 1108. DOI: 10.3390/biom10081108.

Pérez, S.G., Ramos-López, M.A., Zavala-Sánchez, M.A. \& Cárdenas-Ortega N.C. (2010). Activity of essential oils as a biorational alternative to control coleopteran insects in stored grains. Journal of Medicinal Plants Research, 4(25), 2827-2835. DOI: 10.5897/JMPR.9000039.

Phillips, T.W., Jiang, X.L., Burkholder, W.E., Phillips, J.K. \& Tran H.Q. (1993). Behavioral responses to food volatiles by two species of stored-product Coleoptera, Sitophilus oryzae (Curculionidae) and Tribolium castaneum (Tenebrionidae). J. Chem. Ecol., 19(4), 723-734. DOI: 10.1007/ BF00985004.

Piesik, D. \& Wenda-Piesik A. (2015). Sitophilus granarius responses to blends of five groups of cereal kernels and one group of plant volatiles. J. Stored Prod. Res., 62, 36-39. DOI: 10.1016/j.jspr.2015.03.007.

Pimentel, M.A.G., Faroni, L.R.D., Guedes, R.N.C., Sousa, A.H. \& Tótola M.R. (2009). Phosphine resistance in Brazilian populations of Sitophilus zeamais Motschulsky (Coleoptera: Curculionidae). J. Stored Prod. Res., 45(1), 71-74. DOI: 10.1016/j.jspr.2008.09.001.

Plarre, R. (1996). Three-dimensional distribution of Sitophilus granarius (L.) (Coleoptera: Curculionidae) in wheat influenced by the synthetic aggregation pheromone. J. Stored Prod. Res., 32(3), 275-283. DOI: 10.1016/ S0022-474X(96)00015-X.

Raab, A.M., Gebhardt, G., Bolotina, N., Weuster-Botz, D. \& Lang C. (2010). Metabolic engineering of Saccharomyces cerevisiae for the biotechnological production of succinic acid. Metabolic Engineering, 12(6), 518-525. DOI: 10.1016/j.ymben.2010.08.005.

Rivas da Silva, A.C., Lopes, P.M., Barros de Azevedo, M.M., Costa, D.C., Alviano, C.S. \& Alviano D.S. (2012). Biological activities of $\alpha$-pinene and $\beta$-pinene enantiomers. Molecules, 17(6), 6305-6316. DOI: 10.3390/molecules 17066305

Sajeewani, P., Dissanayaka, D., Wijayaratne, L. \& Burks C.S. (2020). Changes in shape, texture and airflow improve efficiency of monitoring traps for Tribolium castaneum (Coleoptera: Tenebrionidae). Insects, 11, 778. DOI: 10.3390/insects 11110778
Serednyak, D.P. \& Fedorenko V.P. (2014). Features of phosphine use against pests of grain ctocks at different stages of their development. Plant Protection and Quarantine, 60, 558-567.

Singh, G. \& Upadhyay R.K. (1993). Essential oils - a potent source of natural pesticides. Journal of Scientific and Industrial Research, 52(10), 676-683.

Small, G.J. (2007). A comparison between the impact of sulfuryl fluoride and methyl bromide fumigations on stored-product insect populations in UK flour mills. J. Stored Prod. Res., 43(4), 410-416. DOI: 10.1016/j. jspr.2006.11.003.

Stuhl, C.J. (2019). Does prior feeding behavior by previous generations of the maize weevil (Coleoptera: Curculionidae) determine future descendants feeding preference and ovipositional suitability? Fla. Entomol., 102(2), 366-372. DOI: 10.1653/024.102.0212.

Ukeh, D.A., Udo, I.A. \& Ogban E.I. (2008). Trapping of stored-product insects using flight traps outside traditional African storage granaries. Journal of Food Agriculture and Environment, 6(2), 399-401.

Vassilakos, T.N., Athanassiou, C.G. \& Tsiropoulos N.G. (2015). Influence of grain type on the efficacy of spinetoram for the control of Rhyzopertha dominica, Sitophilus granarius and Sitophilus oryzae. J. Stored Prod. Res., $64,1-7$

Wakefield, M.E., Bryning, G.P. \& Chambers J. (2005). Progress towards a lure to attract three stored product weevils, Sitophilus zeamais Motschulsky, S. oryzae (L.) and S. granarius (L.) (Coleoptera: Curculionidae). J. Stored Prod. Res., 41(2), 145-161. DOI: 10.1016/j.jspr.2004.01.001.

Wang, J., Zhu, F., Zhou, X.M., Niu, C.Y. \& Lei C.L. (2006). Repellent and fumigant activity of essential oil from Artemisia vulgaris to Tribolium castaneum (Herbst) (Coleoptera: Tenebrionidae). J. Stored Prod. Res. 42(3), 339-347. DOI: 10.1016/j.jspr.2005.06.001.

Wright, R.H. (1966). Primary odors and insect attraction. Can. Entomol., 98(10), 1083-1093. DOI: 10.4039/Ent981083-10.

Yang, Y., Isman, M.B. \& Tak J.H. (2020). Insecticidal activity of 28 essential oils and a commercial product containing Cinnamomum cassia bark essential oil against Sitophilus zeamais Motschulsky. Insects, 11(8), 474 DOI: $10.3390 /$ insects1 1080474.

Yasir, M., Mankin, R.W., Ul Hasan, M. \& Sagheer M. (2020). Residual efficacy of novaluron applied on concrete, metal, and wood for the control of stored product coleopteran pests. Insects, 12(1), 7. DOI: 10.3390/ insects12010007.

Zohry, N.M., Ali, S.A. \& Ibrahim A.A. (2020). Repellency of ten edible and essential native plant oils to the granary weevil, Sitophilus granarius L. (Coleoptera: Curculionidae). Egyptian Academic Journal of Biological Sciences, A, Entomology, 13(4), 187-197. DOI: 10.21608/EAJBSA.2020.126838. 